УДК 159.9:364-785.4:7.02-057.36(045)

DOI https://doi.org/10.26661/2310-4368/2021-4-3

\title{
АРТТЕРАПІЯ У ПСИХОЛОГІЧНІЙ РЕАБІЛІТАЦІЇ ПОРАНЕНИХ КОМБАТАНТІВ В УМОВАХ ГОСПІТАЛЮ
}

\author{
Блінов О. А. \\ доктор психологічних наук, дочент, \\ професор кафедри соиіальних технологій \\ Національний авіачійний університет \\ пр. Любомира Гузара, 1, Київ, Україна \\ orcid.org/0000-0002-9523-0233 \\ blinov09@bigmir.net
}

\begin{abstract}
Ключові слова:
військовослужбовиі,

бойовий стрес, психологічна

реабілітація, музикотерапія, метафоричні асоиіативні карти.
\end{abstract}

У статті наведено результати емпіричного дослідження використання арттерапевтичних методів у процесі психологічної реабілітації поранених учасників бойових дій в умовах військового госпіталю. Підкреслено, що поранення супроводжується значними негативними психологічними та фізіологічними змінами у комбатантів унаслідок впливу бойового стресу. Наведено авторське визначення бойового стресу. Окреслено сучасне бачення фахівцями арттерапії, зміст та особливості використання методів музикотерапії та метафоричних асоціативних карт. Так, в емпіричних дослідженнях упродовж 2014-2018 рр. взяли участь 57 поранених військовослужбовців. У реабілітаційному процесі до учасників бойових дій був застосований авторський психологічний інструментарій у вигляді методики музикотерапії та колод метафоричних асоціативних карт «Стрес-стоп!» та «Компас вибору професії». Метафоричні асоціативні карти застосовувалися індивідуально в роботі 3 усіма категоріями поранених. Групова робота була організована під час проведення сеансів музикотерапії 3 легкопораненими. Наведено результати емпіричного дослідження ефективності застосування арттерапевтичного інструментарію. Для здійснення порівняльного аналізу ефективності психотерапевтичної роботи наведено авторську методику визначення самопочуття, настрою та активності учасників бойових дій до початку терапевтичних заходів, а також після їх завершення. 3'ясовано, що використання арттерапевтичного інструментарію в роботі 3 пацієнтами сприяло покращенню самопочуття, настрою та активності, їхнього психоемоційного стану, що підтверджувалося візуальною діагностикою, суб'єктивною думкою комбатантів та свідченнями персональних лікарів, які організовували їхнє лікування. Доведено результати статистичної обробки даних, які засвідчили наявність кореляційних зв'язків високих рівнів значущості між усіма наведеними показниками. Результати емпіричного дослідження можуть бути використані упсихологічній роботі не тільки 3 пораненими учасниками бойових дій в умовах госпіталю, атакож з іншими категоріями військовослужбовців, у комплексній роботі 3 психопрофілактики впливу бойового стресу. 


\title{
ART-THERAPY IN PSYCHOLOGICAL REHABILITATION WOUNDED COMBATS IN A MILITARY HOSPITAL
}

\author{
Blinov O. A. \\ Doctor of Psychological Sciences, Associate Professor, \\ Professor at the Department of Social Technologies \\ National Aviation University \\ Liubomyra Huzara ave., 1, Kyiv, Ukraine \\ orcid.org/0000-0002-9523-0233 \\ blinov09@bigmir.net
}

Key words: service members, combat stress, psychological rehabilitation, music therapy, metaphorical associative cards.
The article presents the results of an empirical study of the use of arttherapeutic methods in the psychological rehabilitation of wounded combatants in a military hospital. It is emphasized that the wounds are accompanied by significant negative psychological and physiological changes among the combatants as a result of combat stress. The author's definition of combat stress is given. The modern vision of art therapy among the specialists, the content and features of the use of music therapy methods, and metaphorical associative cards are outlined. It is shown that 57 wounded service members took part in empirical researches during 2014-2018. In the rehabilitation process with the service members who took part in hostilities was used the author's psychological tools such as music therapy and decks of metaphorical associative cards "Stress-stop!" and "Compass of choosing a profession". Metaphorical associative cards were used individually for all the categories of the wounded population. Group work was organized during music therapy sessions with the lightly wounded population. The results of an empirical study of the effectiveness of art-therapeutic tools are presented. In order to carry out a comparative analysis of the effectiveness of psychotherapeutic work, the author's method of determining combatants' well-being, mood, and activity (WMA) before the beginning of therapeutic activities, as well as after their completion. It was found that the use of art therapy tools while working with patients has improved their well-being, mood, as well as activity, and their psycho-emotional state, as evidenced by visual diagnosis, subjective opinion of combatants, and according to the physicians who carried out their treatment. The results of statistical data processing are proved, which testifies the correlations of high levels of significance between all the above indicators. The results of empirical research can be used in psychological work not only with wounded service members who took part in hostilities and are in the hospital but also with other categories of service members, in comprehensive work on the combat stress effects.
Постановка проблеми. Бойовий стрес чинить потужну психотравматичну дію на військовослужбовців і негативно впливає на стан їхнього здоров'я, зумовлює виникнення негативних психічних станів, розвиток посттравматичних стресових розладів тощо. Психіка значної кількості комбатантів часто не витримує навантаження побаченого і почутого, що призводить до бойових психічних травм. Проблемою є психотравматизація військовослужбовців, які отримали поранення, стали інвалідами внаслідок виконання службових обов'язків.
Актуальність розгляду цієї теми пов'язана 3 необхідністю організації психотерапевтичної та психокорекційної роботи фахівців із подолання бойових психічних травм у комбатантів, що виникли через вплив бойового стресу. На нашу думку, бойовим стресом $є$ стан психічного напруження військовослужбовців у процесі їхньої адаптації до умов бойової діяльності з використанням ресурсного потенціалу [1].

Організація та проведення психотерапевтичної роботи потребують сучасних ефективних методів, до яких належить арттерапія. Використання 
арттерапевтичних методів дозволяє м'яко обходити кордони психологічного захисту психіки людини, сприяє знаходженню актуальних ресурсів в учасників бойових дій для одужання [2].

Термін «арттерапія» (art - мистецтво, artterapy - терапія мистецтвом) особливо поширений у країнах з англомовним населенням і найчастіше означає лікування за допомогою пластичної образотворчої творчості. У вітчизняній психотерапевтичній літературі також використовуються терміни «ізотерапія» або «художня терапія», однак вони не тотожні англомовному аналогу i дещо звужують його сенс [3, с. 53].

За думкою O.I. Копитіна, під час роботи з психічною травмою та іiі наслідками можуть використовуватися всі види терапії мистецтвом, як окремо, так і в поєднанні одного 3 іншим. Такі інтегровані (у плані експресивних модальностей) види терапії, як правило, називаються полімодальною (інтермодальною) терапією творчістю, або терапією виразними мистецтвами (expressive arts therapies). Візуально-пластичні засоби можуть бути, наприклад, доповнені рольовою грою, рухом чи музикою. Всі ці форми арттерапії можуть бути використані під час роботи 3 посттравматичними розладами [4, с. 20].

Як зазначають О.Л. Вознесенська та М.Ю. Сидоркіна: коли ми визначаємо арттерапію, ми використовуємо поняття «зцілення», тож арттерапія - це спосіб зцілення людини за допомогою творчого самовираження. На нашу думку, «зцілення» - це досягнення клієнтом цілісності, насамперед психічної. I в контексті опанування ним психотравматичного досвіду саме досягнення цілісності набуває особливого значення, тому що відображає процес приєднання травмованої частини особистості, відновлення перерваної лінії життя [5, с. 49].

У психотерапевтичній роботі нами використовувалися методи арттерапії, серед яких: колоди метафоричних асоціативних карт «Стрес-стоп!», «Компас вибору професії» [2; 6], авторська методика музикотерапії [2]. Колода метафоричних асоціативних карт «Стрес-стоп!» затверджена до використання директором Військово-медичного департаменту Міністерства оборони України [7].

Однією 3 проблем психодіагностики в клінічних умовах зі складними пацієнтами, до яких, безумовно, можна віднести поранених, є здійснення оперативної фіксації змін в їхній психічній сфері. Для вирішення цього завдання нами була розроблена 10-бальна експрес-шкала визначення функціонального стану воїнів (СНА), що дозволила швидко встановлювати зміни в їхьому самопочутті, настрої та активності [2, с. 29-31].

Дуже добре зарекомендувала себе в госпітальних умовах музикотерапія, яка дозволяє ефек- тивно здійснювати гармонізацію психічної сфери учасників бойових дій [2]. Музикотерапія - це психотерапевтичний метод, де музика використовується як лікарський засіб [8, с. 392]. Вона реалізується через одночасну дію акустичних хвиль музичної структури на психоемоційну, духовну i тілесну сфери людини.

Метою музикотерапії $є$ відновлення гармонії в душі пацієнта, іiі енергетичного балансу та на цій основі зміцнення психологічного потенціалу пацієнта.

За сучасних умов цей метод отримав подальший розвиток у роботах Л.М. Литвинчук, В.І. Петрушина, Г.Л. Апанасенко, Н.А. Савельєвої-Кулик, О.Г. Сиропятова, Н.А. Дзеружинської, О.В. Друзя, О.З. Безклінської, Г.З. Мороз, І.О. Черненко та інших [9; 10].

У практичній роботі нами застосовується авторська методика музичної терапії. Вона має організаційну та виконавчу частини. В організаційній частині методики здійснюється інформаційна робота 3 оповіщення пацієнтів про час проведення сеансів музикотерапії, формування мотивації та підвищення зацікавленості пацієнтів у відвідуванні занять. До виконавчої частини належить безпосередньо процес ії проведення [2].

За необхідності проводиться контроль функціональних станів самопочуття, настрою й активності за допомогою опитувальника «СНА» до та після сеансу музикотерапії.

Практика проведення музикотерапії свідчить, що після відвідування першого сеансу, як правило, понад 50 \% пацієнтів прийдуть і на наступні.

Під час сеансу здійснюється прослуховування музичних творів класичного репертуару (Моцарта, Бетховена, Чайковського тощо). Тривалість сеансу - 37 хвилин.

Одним із сучасних методів арттерапії є метафоричні асоціативні карти [2; 6]. Провідними фахівцями зі створення та роботи 3 метафоричними асоціативними картами на пострадянському просторі є Г.Б. Кац, К.О. Мухаматуліна, С.Р. Морозівська, Н.С. Вернікова, О.М. Тараріна, К.Л. Мілютіна, В.А. Муромець, В.С. Ратеєва [11; 12].

Метафоричні асоціативні карти $\epsilon$ новаторським і надзвичайно ефективним інструментарієм практичної психології та психотерапії.

На думку Н.С. Вернікової, метафоричні асоціативні карти - це універсальний психологічний інструмент, що базується на метафорі, апелює до підсвідомості людини і застосовується для діагностики, корекції, розвитку, розкриття творчих здібностей та коучингу [11].

Як зазначає Є.P. Морозівська, метафоричні асоціативні карти - це інструмент арттерапії, що застосовується психологами різних терапевтичних шкіл в індивідуальній, сімейній та груповій 
роботі 3 клієнтами будь-якого віку, будь-якого рівня освіти, без обмежень за національними та релігійними ознаками. Цей інструмент використовується для проєктивної психодіагностики, консультування і психокорекції [12].

На переконання Г.Б. Кац і К.О. Мухаматуліна, метафоричні карти називають ще асоціативними (вони викликають асоціації, завдяки яким людина проживає ще раз свою історію, актуалізує проблему), проєктивними (людина бачить у карті саме те, що хоче бачити, те, що емоційно висловлюється в ній), терапевтичними. Все це робить метафоричні карти унікальним, схожим на гру інструментарієм, який може використовуватися в консультуванні, психотерапії, коучингу, груповій та індивідуальній роботі 3 дітьми і дорослими [13].

На нашу думку, метафоричні асоціативні карти - це психологічний інструментарій роботи фахівця, за допомогою якого корекція i розвиток емоційної сфери особистості досягаються через іiі метафоричне, образне (асоціативне) мислення [2, с. 8$]$.

Метафоричні асоціативні карти застосовуються як для психодіагностики, психотерапії, так i для психокорекції. Вони консолідують роботу обох півкуль головного мозку, що призводить до виявлення нових способів мислення, набуття свіжого погляду на проблему, виникнення інсайтів.

Під час роботи 3 пораненими і контуженими військовослужбовцями метафоричні асоціативні карти дозволяють налагодити конструктивний діалог між пацієнтом і психологом. У зв'язку з масовою відмовою комбатантів від роботи 3 традиційними методами психодіагностики (анкетуванням, бланковими тестовими методиками, автоматизованими психологічними методиками на базі ПЕОМ тощо) метафоричні асоціативні карти дозволяють не тільки оперативно провести психодіагностику пацієнтів, але і сприяють у вирішенні багатьох психологічних проблем.

Нами були використані на практиці авторські колоди метафоричних асоціативних карт «Стресстоп!» і «Компас вибору професії» [2].

Колода метафоричних асоціативних фотокарт «Стрес-стоп!» як психотерапевтичний та психокорекційний інструментарій дозволяє змістовно здійснювати профілактику бойового стресу, організовувати роботу з подолання негативних наслідків його впливу.

Колода метафоричних карт «Компас вибору професії» призначена для розкриття свідомих i несвідомих виборів професійної діяльності людини, здійснення аналізу їі мотиваційних переваг, для вивчення і полегшення вибору професії людиною. Особливо актуальна робота з цією колодою карт для учасників бойових дій, які отри- мали важкі поранення і змушені здобувати нову професію.

Мета статті - розкрити зміст арттерапії та представити результати емпіричного дослідження успішності використання госпітальними психологами арттерапевтичного інструментарію в роботі 3 пораненими учасниками бойових дій.

Виклад основного матеріалу. Арттерапія постраждалих комбатантів в умовах військового госпіталю $є$ одним із різновидів арсеналу інструментарію психолога у проведенні психологічної реабілітації учасників бойових дій.

Психологічна реабілітація - це система заходів, спрямованих на відновлення, корекцію психологічних функцій, якостей, властивостей особи (військовослужбовця), створення сприятливих умов для розвитку й утвердження особистості [14].

Під психологічною реабілітацією поранених та інвалідів доцільно розуміти діяльність суб' єктів психологічної роботи із відновлення психічних функцій, якостей, особистісних властивостей і системи відносин особистості військовослужбовця, що дозволять йому успішно функціонувати у мирному соціумі. Це комплекс організаційних і психологічних заходів, які спрямовані на повернення свідомості людини до звичайного для неї образу життя та праці, створення сприятливих умов для розвитку та утвердження особистості [1].

Проведення психологічної реабілітації у військовому госпіталі має певні особливості та відрізняється від інших місць її проведення [15; 16].

Згідно з сучасними думками фахівців військово-медичної служби психологічна реабілітація проводиться під час загального процесу медико-психологічної реабілітації на третьому рівні надання допомоги комбатантам [17].

В емпіричних дослідженнях подолання наслідків бойового стресу за допомогою арттерапевтичних методів упродовж 2014-2018 рр. взяли участь 57 військовослужбовців. Вибірка пацієнтів була різнорідною за складом учасників, складністю отриманих поранень, часом перебування в умовах бойових дій та в госпіталі, статтю, віком тощо. Робота з метафоричними асоціативними картами була персональною в усіх категоріях поранених. Групова робота була організована під час проведення сеансів музикотерапії з легкопораненими [1;2].

Для здійснення порівняльного аналізу ефективності психотерапевтичної роботи нами використовувалась авторська методика визначення самопочуття, настрою та активності учасників бойових дій (СНА) до початку терапевтичних заходів, а також після їх завершення.

Під час проведення психотерапевтичної роботи 3 військовослужбовцями в умовах госпіталю 3 використанням психологічного інструментарію були отримані такі результати (табл. 1). 
Таблиця 1

Середні значення показників самопочуття, настрою та активності, отримані внаслідок використання психологічного інструментарію (у балах)

\begin{tabular}{|c|c|c|c|c|}
\hline \multicolumn{2}{|c|}{ Тип методики } & Самопочуття & Настрій & Активність \\
\hline \multirow{3}{*}{ МАК «Стрес-стоп!» } & Середнє до & 7,25 & 7,05 & 6,6 \\
\cline { 2 - 5 } & Середнє після & 8,15 & 8,65 & 8,35 \\
\cline { 2 - 5 } & $\mathrm{N}$ & 20 & 20 & 20 \\
\hline \multirow{3}{*}{$\begin{array}{c}\text { МАК «Компас } \\
\text { вибору професії }\end{array}$} & Середнє до & 6,06 & 6,29 & 5,06 \\
\cline { 2 - 5 } & Середнє після & 7,06 & 7,35 & 5,94 \\
\cline { 2 - 5 } & $\mathrm{N}$ & 17 & 17 & 5,4 \\
\hline \multirow{3}{*}{ Музико-терапія } & Середнє до & 5,55 & 7,35 & 7,05 \\
\cline { 2 - 5 } & Середнє після & 7,45 & 20 & 20 \\
\cline { 2 - 5 } & $\mathrm{N}$ & 20 & & 17 \\
\hline
\end{tabular}

Якщо до початку роботи лідерські позиції займав показник «Самопочуття» $(7,25$ бала), то після завершення психотерапевтичної роботи домінуючі позиції перейшли до показника «Настрій» $(8,65$ бала).

Результати використання колоди МАК «Компас вибору професії» показали, що найвищий рівень має «Настрій» (6,29 бала), а найнижчий «Активність» $(5,06$ бала).

У результаті роботи показник «Самопочуття» підвищився на $14 \%$ і становив 7,06 бала. Показник «Активність» виріс на $15 \%$ і становив 5,94 бала. Показник «Настрій» підвищився на $14 \%$ i показав найвищий рівень серед інших показників - 7,35 бала.

До початку сеансів музикотерапії у пацієнтів встановлено рівень показника «Самопочуття» - 5,55 бала, «Активність» $-5,4$ бала, найвищий рівень має показник «Настрій» із 6,15 бала.

Внаслідок проведеної терапевтичної роботи рівень «Самопочуття» підвищився на $26 \%$ і становив 7,45 бала. «Настрій» підвищився на $16 \%$ i досягнув рівня у 7,35 бала. «Активність» дорівнює 7,05 бала, що на $23 \%$ більше його початкового рівня.
Таким чином, під час застосування психологічного інструментарію в пацієнтів відзначалося покращення самопочуття, настрою та активності, психоемоційного стану, що підтверджувалося візуальною діагностикою, суб' єктивною думкою пацієнтів та свідченнями персональних лікарів, які організовували їхнє лікування.

Під час проведення сеансу музикотерапії (при цьому для прослуховування використовувалися класичні музичні твори) в одного 3 пацієнтів-військовослужбовців поліпшення психоемоційного стану не спостерігалось у зв'язку з тим, що він був прихильником рок музики.

Оцінювання значущості отриманих результатів здійснювалося за допомогою Т-критерію Вілкоксона. 3 одержаними результатами можна ознайомитися в табл. 2.

Аналіз отриманих результатів засвідчив значну кількість значущих відмінностей між показниками методик за $\mathrm{p}<0,01, \mathrm{p}<0,05$.

Використання психологічного інструментарію у вигляді МАК, музикотерапії за показниками «Самопочуття» та «Настрій» дозволяє встановити за всіма статистичними процедурами значущі відмінності на рівні $\mathrm{p}<0,01$.

Таблиця 2

Зведена таблиця методів і критеріїв

\begin{tabular}{|c|c|c|c|c|c|c|c|}
\hline & \multirow{2}{*}{ Кількість } & \multicolumn{2}{|c|}{ Самопочуття } & \multicolumn{2}{c|}{ Настрій } & \multicolumn{2}{c|}{ Активність } \\
\cline { 3 - 8 } & $\begin{array}{c}\text { Z-крите- } \\
\text { рій }\end{array}$ & $\begin{array}{c}\text { Значу- } \\
\text { щість }\end{array}$ & $\begin{array}{c}\text { Z-крите- } \\
\text { рій }\end{array}$ & $\begin{array}{c}\text { 3начу- } \\
\text { щість }\end{array}$ & $\begin{array}{c}\text { Z-крите- } \\
\text { рій }\end{array}$ & $\begin{array}{c}\text { Значу- } \\
\text { щість }\end{array}$ \\
\hline $\begin{array}{c}\text { МАК } \\
\text { «Стрес-стоп!»** }\end{array}$ & 20 & $-2,705 \mathrm{a}$ & 0,007 & $-2,981 \mathrm{a}$ & 0,003 & $-3,158 \mathrm{a}$ & 0,002 \\
\hline $\begin{array}{c}\text { МАК «Компас вибору } \\
\text { професії»** }\end{array}$ & 17 & $-2,582 \mathrm{a}$ & 0,01 & $-2,941 \mathrm{a}$ & 0,003 & $-2,358 \mathrm{a}$ & $0,018^{*}$ \\
\hline Музикотерапія** & 20 & $-3,658 \mathrm{a}$ & 0,000 & $-3,482 \mathrm{a}$ & 0,000 & $-2,945 \mathrm{a}$ & 0,003 \\
\hline
\end{tabular}

**Кореляція, значуща на рівні 0,01

*Кореляція, значуща на рівні 0,05 
За показником «Активність» в разі використання МАК «Стрес-стоп!» і музикотерапії існують значущі відмінності на рівні $\mathrm{p}<0,01$. За використання МАК «Компас вибору професії» встановлені значущі відмінності на рівні р $<0,05(0,018)$.

Порівняльний аналіз результатів психотерапевтичної роботи продемонстрував високий рівень її ефективності. Практично всі кореляційні зв'язки мають високі рівні значущості.

Висновки. Результати емпіричного дослідження та отримані статистичні дані засвідчують актуальність використання арттерапевтичних методів у процесі психологічної реабілітації поранених учасників бойових дій в умовах військового госпіталю.

У психотерапевтичній роботі використовувались авторські метафоричні асоціативні карти «Стрес-стоп!», «Компас вибору професії» і методика музикотерапії. Для фіксації змін застосовувалась експрес-шкала «СНА».

Використання психологічного інструментарію в роботі з пораненими комбатантами сприяло покращенню самопочуття, настрою та активності, психоемоційного стану, що підтверджувалося візуальною діагностикою, суб' єктивною думкою пацієнтів та свідченнями персональних лікарів, які організовували їхнє лікування.

Результати статистичної обробки даних засвідчили наявність кореляційних зв'язків високих рівнів значущості між усіма показниками психологічного інструментарію.

Отримані результати психотерапевтичної роботи довели, що психологічний інструментарій $\epsilon$ ефективним засобом подолання наслідків бойового стресу. Вагомим підсумком нашої роботи вважаємо підвищення рівня емоційного комфорту та впевненості особистості в собі, що дає надію на їі швидше одужання.

Висновки емпіричного дослідження можуть бути використані у психологічній роботі не тільки 3 пораненими учасниками бойових дій в умовах госпіталю, а також з іншими категоріями військовослужбовців, у комплексній роботі з психопрофілактики впливу бойового стресу.

\section{ЛІТЕРАТУРА}

1. Блінов О.А. Бойова психічна травма : монографія. Київ : Талком, 2019. 700 с.

2. Блінов О.А. Інноваційний психологічний інструментарій діагностики, психотерапії та психокорекції бойового стресу : навчально-методичний посібник. Київ : Талком, 2020. 136 с.

3. Арт-терапия. Психотерапевтическая энииклопедия / под ред. Б.Д. Карвасарского. 2-е изд., доп. и перераб. Санкт-Петербург : Питер, 2002. 1024 с.

4. Копытин А.И. Методы арт-терапии в преодолении последствий травматического стресса. Москва : Когито-Центр, 2014. 203 с.

5. Вознесенська О.Л., Сидоркіна М.Ю. Арттерапія у подоланні психічної травми : практичний посібник. Київ : Золоті ворота, 2015. 198 с.

6. Блінов О.А., Шопіна М.О. Метафоричні асоціативні карти як творчий інтегративний ресурс стресостійкості особистості : навчальний посібник. Київ : Талком, 2016. 123 с.

7. Клінічні рекомендації щодо застосування методів психодіагностики та медико-психологічної реабілітації у лікарняних та санаторно-курортних закладах Міністерства оборони України / П.І. Мех та ін. / за заг. ред. В.В. Стеблюка, А.М. Галушки. Київ, 2017. 266 с.

8. Музыкотерапия. Психотерапевтическая энииклопедия / под ред. Б.Д. Карвасарского. 2-е изд., доп. и перераб. Санкт-Петербург : Питер, 2002. 1024 с.

9. Петрушин В.И. Музыкальная психотерапия. Теория и практика : учебное пособие. Москва : ВЛАДОС, 2011. $176 \mathrm{c.}$

10. Практичні аспекти використання музикотерапії в комплексній реабілітації учасників антитерористичної операції : методичні рекомендації / О.В. Друзь та ін. Київ : ТзОВ «Растр-7», 2015. $20 \mathrm{c}$.

11. Верникова Н.С. Метафорические ассоциативные карты - универсальный инструмент для МАКсимальных результатов. Практическая психология. Винница : ЧП «ТД «Эдельвейс и К», 2014. $124 \mathrm{c}$.

12. Морозовская Е.Р. Проективные карты в работе психолога: полное руководство. Одесса : Институт проективных карт, 2013. 116 с.

13. Кац Г.Б., Мухаматулина Е.А. Метафорические карты: руководство для психолога. 4-е изд. Москва : Генезис, 2015. 160 с.

14. Про затвердження Положення про психологічну реабілітацію військовослужбовців ЗС України та Державної спеціальної служби транспорту, які брали участь в АТО/ООС, здійснювали заходи із забезпечення національної безпеки й оборони, відсічі і стримування збройної агресії Російської Федерації у Донецькій та Луганській областях чи виконували службові (бойові) завдання 
в екстремальних умовах : Наказ Міністерства оборони України від 9 грудня 2015 р. № 702 у редакції Наказу МОУ від 11 грудня 2019 р. № 629.

15. Організація роботи відділення психологічної реабілітації в Національному військово-медичному клінічному центрі «Головний військовий клінічний госпіталь» : інформаційно-методичний посібник. Київ : Видавництво «Людмила», 2021. 64 с.

16. Блінов О.А. Особливості організації психологічної абілітації та реабілітації в умовах військового госпіталю. Актуальні проблеми психологічної допомоги, сочіальної та медико-психологічної реабілітації учасників антитерористичної операції : матеріали міжвідомчої науково-практичної конференції, м. Київ, 26 травня 2016 р. Київ : НУОУ, 2016. С. 45-47.

17. Порядок організації та проведення медико-психологічної реабілітації військовослужбовців Збройних сил України : методичні рекомендації / В.В. Стеблюк та ін. Київ, 2017. 56 с.

\section{REFERENCES}

1. Blinov, O.A. (2019) Boiova psykhichna travma : monohrafiia. K. : Talkom. [in Ukrainian]

2. Blinov, O.A. (2020) Innovatsiinyi psykholohichnyi instrumentarii diahnostyky, psykhoterapii ta psykhokorektsii boiovoho stresu: navch.-metod. posibnyk. K. : Talkom. [in Ukrainian]

3. Artterapiya (2002) Psihoterapevticheskaya entsiklopediya / pod red. B.D. Karvasarskogo. 2-e izd., dop. i pererab. SPb. : Piter. [in Russian]

4. Kopyitin, A.I. (2014) Metodyi art-terapii v preodolenii posledstviy travmaticheskogo stressa. M. : Kogito-Tsentr. [in Russian]

5. Voznesenska, O.L., Sydorkina, M.Yu. (2015) Art-terapiia u podolanni psykhichnoi travmy : praktychnyi posibnyk. K. : Zoloti vorota. [in Ukrainian]

6. Blinov, O.A., Shopina, M.O. (2016) Metaforychni asotsiatyvni karty yak tvorchyi intehratyvnyi resurs stresostiikosti osobystosti : navch. posib. K. : Talkom. [in Ukrainian]

7. Klinichni rekomendatsii shchodo zastosuvannia metodiv psykhodiahnostyky ta medyko-psykholohichnoi reabilitatsii u likarnianykh ta sanatorno-kurortnykh zakladakh Ministerstva oborony Ukrainy (2017) / P.I. Mekh ta in. / za zah. red. V.V. Stebliuka, A.M. Halushky. Kyiv. [in Ukrainian]

8. Muzyikoterapiya (2002) Psihoterapevticheskaya entsiklopediya / pod red. B.D. Karvasarskogo. 2-e izd., dop. i pererab. SPb. : Piter. [in Russian]

9. Petrushin, V.I. (2011) Muzyikalnaya psihoterapiya. Teoriya i praktika : ucheb. posobie. M. : VLADOS. [in Russian]

10. Praktychni aspekty vykorystannia muzykoterapii v kompleksnii reabilitatsii uchasnykiv antyterorystychnoi operatsii (2015). Metodychni rekomendatsii / O.V. Druz ta in. K. : TzOV "Rastr-7". [in Ukrainian]

11. Vernikova, N.S. (2014) Metaforicheskie assotsiativnyie karty - universalnyiy instrument dlya MAKsimalnyih rezultatov. Prakticheskaya psihologiya. Vinnitsa : ChP "TD "Edelveys i K". [in Ukrainian]

12. Morozovskaya, E.R. (2013) Proektivnyie karty v rabote psihologa: polnoe rukovodstvo. Odessa : In-t Proektivnyih kart. [in Ukrainian]

13. Kats, G.B., Muhamatulina, E.A. (2015) Metaforicheskie kartyi: rukovodstvo dlya psihologa. 4-e izd. M. : Genezis. [in Russian]

14. Nakaz Ministerstva oborony Ukrainy (MOU) vid 09.12.2015 r. № 702 u redaktsii nakazu MOU vid 11.12.2019 r. № 629 "Pro zatverdzhennia Polozhennia pro psykholohichnu reabilitatsiiu viiskovosluzhbovtsiv ZS Ukrainy ta Derzhavnoi spetsialnoi sluzhby transportu, yaki braly uchast v ATO/OOS, zdiisniuvaly zakhody iz zabezpechennia natsionalnoi bezpeky i oborony, vidsichi i strymuvannia zbroinoi ahresii Rosiiskoi Federatsii u Donetskii ta Luhanskii oblastiakh chy vykonuvaly sluzhbovi (boiovi) zavdannia v ekstremalnykh umovakh". [in Ukrainian]

15. Orhanizatsiia roboty viddilennia psykholohichnoi reabilitatsii v Natsionalnomu viiskovo-medychnomu klinichnomu tsentri "Holovnyi viiskovyi klinichnyi hospital" (2021): informatsiino-metodychnyi posibnyk. Kyiv: "Vydavnytstvo Liudmyla". [in Ukrainian]

16. Blinov, O.A. (2016) Osoblyvosti orhanizatsii psykholohichnoi abilitatsii ta reabilitatsii v umovakh viiskovoho hospitaliu. Aktualni problemy psykholohichnoi dopomohy, sotsialnoi ta medyko-psykholohichnoi reabilitatsii uchasnykiv antyterorystychnoi operatsii : materialy mizhvidomchoi naukovo-praktychnoi konferentsii (Kyiv, 26 travnia 2016 r.). Kyiv : NUOU. Pp. 45-47. [in Ukrainian]

17. Poriadok orhanizatsii ta provedennia medyko-psykholohichnoi reabilitatsii viiskovosluzhbovtsiv Zbroinykh Syl Ukrainy (2017): metod. rekom. / V.V. Stebliuk ta in. Kyiv. [in Ukrainian] 